\title{
Water Quality Characteristic of Ciliwung River at Bogor Botanical Garden Segmen, Bogor
}

\author{
Agus Priyono, Siti Badriyah Rushayati, Aditya Bagus Sujati \\ Department of Forest Resource Conservation, Faculty of Forestry and Environment, IPB University, Bogor, Indonesia \\ Email address: \\ gusno128@yahoo.com (A. Priyono)

\section{To cite this article:} \\ Agus Priyono, Siti Badriyah Rushayati, Aditya Bagus Sujati. Water Quality Characteristic of Ciliwung River at Bogor Botanical Garden \\ Segmen, Bogor. International Journal of Energy and Environmental Science. Vol. 6, No. 5, 2021, pp. 122-127. \\ doi: $10.11648 /$ j.ijees.20210605.12
}

Received: May 7, 2021; Accepted: August 2, 2021; Published: September 6, 2021

\begin{abstract}
The Ciliwung River is one of the heavily polluted rivers in Indonesia. This is caused by the input of high population and industrial pollution loads along the river, from upstream in the recreation area and Puncak in Bogor Regency to through Bogor City, Depok City and downstream in the Jakarta metropolitan city. This condition is worsened by the decreasing vegetated land in the Ciliwung watershed, especially in the river border which is polluted by the increasing population and the development of various industries, which generally do not have sewage treatment units, so that the Ciliwung river is declared heavily polluted. Bogor Botanical Gardens (BBG) is one of the green open spaces that acts as a buffer for the Ciliwung River in the BBG section. This study aims to analyze changes in the water quality of the Ciliwung river along the BBG. The research was conducted by analyzing air quality based on physicochemical factors (temperature, turbidity, total solids, $\mathrm{pH}, \mathrm{DO}, \mathrm{BOD}$, $\mathrm{COD}$ ) and benthic community structure at BBG inlet, middle BBG, and BBG outlet. The physico-chemical parameters of the Ciliwung river in the BBG segment still meet the requirements of class II water quality standards except for COD. The macrozoobenthos community structure is dominated by the orders Ephemeroptera and Trichoptera. Air quality analysis using the Water Quality Index, Pollution Index, Shannon-Wiener Diversity Index and the Hilsenhoff Biotic Index showed an increase in air quality from BBG inlet, middle BBG to BBG outlet.
\end{abstract}

Keywords: Green Open Space, Macrozoobenthos, Purification

\section{Introduction}

The Ciliwung River is a cross-provincial river that flows from its upstream area in the Puncak area of Bogor Regency (West Java Province) to its mouth in Jakarta Bay (DKI Jakarta province). Due to population pressure and increasing economic activity, the quality of this river water has been heavily polluted (Ministry of Environment KLH, 2010) from its upstream. Trofisa (2011) in his research states that the sources of polluting water from the Ciliwung River in Bogor City include domestic/household waste, industry, livestock and agriculture [17].

Naturally, the river ecosystem basically has the power to naturally recover (self purification) to assimilate all the pollutants that enter the river. However, this purification ability is highly dependent on the intensity of pollutants from the surrounding environment. If the input of pollutants from the surrounding environment continues, the purification power of this river will not be able to keep up with the rate of pollution load. The result is that although the river has the ability to purify, the water quality of the river will continue to deteriorate.

Based on these facts, the existence of green open spaces around river boundaries actually plays a role in increasing the rate of water recovery. The green open space acts as a filter to reduce the input of outside pollutants so that the water recovery rate will be greater than the rate of water pollution. Bogor Botanical Gardens is one of the green open spaces which has a very important role in maintaining the quality of the environment in the city of Bogor. The existence of this botanical garden has provided many environmental service benefits to the community in Bogor City. This green open space not only provides microclimate and aesthetic benefits for the City of Bogor, but also functions as a green segment of the Ciliwung River for the purification process to take place. The urgency of this research is to find out how big the role of the Bogor Botanical Gardens is in helping the water 
recovery (purification) of the Ciliwung River. The research was carried out by measuring changes in the water quality of the Ciliwung River before and after passing through the Bogor Botanical Gardens using physical-chemical parameters as well as biotic parameters.

The purpose of this study was to analyze changes in the water quality of the Ciliwung River in the upstream (inlet), middle and downstream (outlet) segments of the Bogor Botanical Gardens.

\section{Method}

The research was conducted from 26 January 2017 to 6 March 2017 located in the Ciliwung River, Bogor Botanical Gardens segment, located in Bogor City, West Java. The location for sampling of water and macrozoobenthic biota was carried out at 3 points, namely at the inlet (under the Otista bridge), in the middle and at the Bogor Botanical Gardens outlet (under the Sempur bridge).

The tools used in this research include: surber to take macrozoobenthic samples, water sample bottles, macrozoobenthic filters, length measuring instruments, floats, stopwatches, writing instruments, tally sheets and macrozoobenthos guidebooks. The materials used are macrozoobenthic biota samples, water and alcohol samples.

Types of data collected include: (1) physical conditions of the waters such as: width, current velocity and type of riverbed substrate; (2) the physical and chemical quality of water includes: dissolved oxygen (DO), Biological Oxygen Demand (BOD), Chemical Oxygen Demand (COD), pH, TSS and turbidity; and (3) the macrozoobenthic community.

Macrozoobenthos data analysis included biota density, diversity and Hilsenhoff index. The water quality data were analyzed for compliance with the water quality of the Ciliwung River in Bogor City (Class II - Government Regulation No. 82 of 2001), as well as the water pollution index.

Water Quality Index (WQI)

Water quality status is determined by using the National Sanitation Foundation Water Quality Index (NSF-WQI) or Water Quality Index (IKA) reference. Calculation of the Water Quality Index is carried out with the following formula (Ott 1978) [12]:

$$
\mathrm{WQI}=\sum_{k=0}^{n} W i \cdot L i
$$

where:

WQI=Water Quality Index

$\mathrm{Wi}=$ Weight of each parameter (Table 1)

$\mathrm{Li}=$ Value of the sub-index curve

$\mathrm{n}=$ Number of water quality parameters

The parameters used in calculating the Water Quality Index and the weight of each parameter can be seen in Table 1 .

Table 1. Parameters and weights of parameters in calculating the water quality index.

\begin{tabular}{lllll}
\hline No & Parameters & Parameter weights (wa) & Adjustment parameter weights (wb) & Unit \\
\hline 1 & Dissolved oxygen & 0.17 & 0.20 & \\
2 & pH & 0.11 & 0.13 & \\
3 & BOD & 0.11 & 0.13 & \\
4 & Temperature & 0.10 & 0.12 & $\mathrm{mg} / \mathrm{L}$ \\
5 & Turbidity & 0.08 & 0.10 & ${ }^{\circ} \mathrm{C}$ \\
6 & Total solid & 0.07 & 0.08 & $\mathrm{NTU}$ \\
7 & Nitrat (NO3) & 0.10 & 0.12 & $\mathrm{mg} / \mathrm{L}$ \\
8 & Total phosphat & 0.10 & 0.12 & $\mathrm{mg} / \mathrm{L}$ \\
\hline
\end{tabular}

Water quality classification are classified into 5 categories according to Brown et al. (1970) which can be seen in Table 2.

Table 2. Classification of Water Quality.

\begin{tabular}{lll}
\hline No. & Value & Criteria \\
\hline 1 & $0-25$ & Very bad \\
2 & $26-50$ & Bad \\
3 & $51-70$ & Moderate \\
4 & $71-90$ & Well \\
5 & $91-100$ & Very good \\
\hline
\end{tabular}

Pollution Index (IP)

The formula for calculating the Pollution Index (Decree of the State Minister for the Environment Number: 115 of 2003) is:

$$
\mathrm{PIj}=\sqrt{\frac{(C i / L i j)_{m}^{2}+C i / L i j_{r}^{2}}{2}}
$$

Where:

$\mathrm{Lij}=$ the concentration of the ith water quality parameter in the jth Water Allocation Standard

$\mathrm{Ci}=$ concentration of the water quality parameter of the I sampling results

$\mathrm{Ci} /$ Lijr=average $\mathrm{Ci} / \mathrm{Li}$ ratio

$\mathrm{Ci} / \mathrm{Lijm}=$ maximum $\mathrm{Ci} / \mathrm{Li}$ ratio

$\mathrm{PIj}=$ Pollution Index

Evaluation of the PI value is:

$0 \leq \mathrm{PIj} \leq 1,0$ : good condition (meet quality standard)

$1.0<\mathrm{PIj} \leq 5.0$ : lightly polluted

$5.0<\mathrm{PIj} \leq 10.0$ : moderately polluted

PIj $>10.0$ : heavily polluted

Diversity Index

Macrozoobenthic diversity can be calculated using the Shannon-wiener diversity index with the following formula (Magurran 2004) [9]:

$$
\mathrm{H}^{\prime}=-\sum p i \ln p i
$$

Where:

$\mathrm{H}^{\prime}=$ Shannon-wiener Diversity Index

$\mathrm{pi}=$ The ratio of the number of individuals of a certain type to the number of individuals whole individual $(\mathrm{n} / \mathrm{N})$. 
The range of values from the Shannon-Wiener index can show the quality of water seen from the level of diversity of mecrozoobenthos in these waters. According to Lee et al (1978) the interpretation of the Shannon-Wiener index value on water quality is as shown in Table 3.

Table 3. Classification of Pollution Levels based on Diversity Index.

\begin{tabular}{ll}
\hline Pollution Levels & Diversity Index \\
\hline Not polluted & $>2.0$ \\
Lightly polluted & $1.6-2.0$ \\
Moderately polluted & $1.0-1.5$ \\
Heavily polluted & $<1,5$ \\
\hline
\end{tabular}

Hilsenhoff Biotic Index (HBI)

Hilsenhoff's biotic index is a biotic index used as a parameter to estimate water quality. This index can better indicate water quality because it considers the tolerance level value of each type of macrozoobenthos. The Hilsenhoff Biotic Index formula is as follows (Hilsenhoff 1982):

$$
\mathrm{HBI}=\sum \frac{n i x t i}{N}
$$

Where:

$\mathrm{HBI}=$ Hilsenhoff Biotic Index

$\mathrm{ni}=$ the number of individuals of type i macrozoobenthos

ti $=$ tolerance value for type $\mathrm{i}$

$\mathrm{N}=$ total number of macrozoobenthic individuals

The results of this index calculation can be interpreted regarding water quality and the level of pollution as can be seen in Table 4.

Table 4. Classification of Water Quality based on Hilsenhoff Biotic Index (HBI).

\begin{tabular}{lll}
\hline Indeks Biotic Hilsenhoff & Water Quality & Pollution Levels \\
\hline $0.00-3.75$ & Excellence & Not polluted \\
$3.76-4.25$ & Very good & A little polluted \\
$4.26-5.00$ & Good & Polluted \\
$5.01-5.75$ & Moderate & Slightly Polluted \\
$5.76-6.50$ & Little bad & Heavy polluted \\
$6.51-7.25$ & Bad & More heavy polluted \\
$7.26-10.00$ & Very bad & Very heavy polluted \\
\hline
\end{tabular}

\section{Results and Discussion}

The condition of the Ciliwung River Bogor Botanical
Gardens segment has a length of $1200 \mathrm{~m}$, and an average width of $17 \mathrm{~m}$, a current speed of $1.03 \mathrm{~m} / \mathrm{s}$ and a water discharge of $329.62 \mathrm{~m}^{3} / \mathrm{s}$.

According to Macon and Welch (1980) in Bakti (1991) the type of flow is very fast $>1 \mathrm{~m} / \mathrm{sec}$, classified into rivers with very fast currents [1].

The riverbed substrate is dominated by rocks and gravel. The river flow velocity greatly influences the improvement of the purification process. The current velocity will create turbulence on the water surface, thereby expanding the area of oxygen diffusion from the air into the water. High levels of oxygen (DO) in the waters will increase the chemical oxidation process of pollutants and help aquatic organisms to decompose organic pollutants.

Water Quality

The results of the water quality analysis (physical and chemical parameters) at the inlet, center and outlet of the BBG obtained an average of each parameter as presented in Table 5. The standard values for physical and chemical parameters in this study refer to Government Regulation No. 82 of 2001 concerning Water Quality Management and Water Pollution Control with Class II Water Quality Standards (WQS).

Table 5. Results of water quality analysis.

\begin{tabular}{llllll}
\hline \multirow{2}{*}{ No } & \multirow{2}{*}{ Parameter } & WQS & Lokasi & & \\
\cline { 4 - 6 } & & Class II & Inlet & BBG & Outlet \\
\hline 1 & Turbidity (NTU) & - & 5,5 & 4,23 & 5,57 \\
2 & TSS (mg/L) & 50 & 36,48 & 22,03 & 26,65 \\
3 & Temperature $\left({ }^{\circ} \mathrm{C}\right)$ & dev. 3 & 25 & 24 & 23 \\
4 & pH & $6-9$ & 6,7 & 6,8 & 7,0 \\
5 & DO (mg/L) & 4,0 & 5,8 & 4,9 & 5,6 \\
6 & BOD (mg/L) & 3,0 & 8,5 & 3,7 & 2,2 \\
7 & COD $(\mathrm{mg} / \mathrm{L})$ & 25,0 & 43,1 & 64,8 & 56,3 \\
\hline
\end{tabular}

In general, the water quality condition of the Ciliwung River has increased from the inlet to the outlet. Referring to Government Regulation 82/2001, the physical-chemical parameters of the Ciliwung River in the Bogor Botanical Gardens segment still meet the water quality standards for class II. Chemical parameters, especially BOD at the outlet, have met BMA class II, while COD at the three sampling locations has exceeded the class II water quality standard ( $>$ $25 \mathrm{mg} / \mathrm{l})$.

Table 6. Macrozoobenthic sampling results.

\begin{tabular}{|c|c|c|c|c|}
\hline Famili & Ordo & Inlet (individu) & BBG (individu) & Outlet (individu) \\
\hline Baetidae & Ephemeroptera & 44 & 50 & 46 \\
\hline Calopterygidae & Odonata & 0 & 0 & 1 \\
\hline Cloroperlidae & Plecoptera & 0 & 0 & 6 \\
\hline Decapoda & Decapoda & 0 & 1 & 0 \\
\hline Docolopodidae & Diptera & 0 & 0 & 1 \\
\hline Dryopidae & Coleoptera & 2 & 0 & 3 \\
\hline Elmidae & Coleoptera & 3 & 1 & 10 \\
\hline Hirudinea & Hirudinea & 3 & 4 & 4 \\
\hline Hydrophilidae & Diptera & 0 & 3 & 2 \\
\hline Hydropsychidae & Trichoptera & 9 & 69 & 33 \\
\hline Perlodidae & Plecoptera & 3 & 7 & 0 \\
\hline Phryganeidae & Trichoptera & 0 & 0 & 1 \\
\hline Psephenidae & Coleoptera & 1 & 0 & 0 \\
\hline
\end{tabular}




\begin{tabular}{lllll}
\hline Famili & Ordo & Inlet (individu) & BBG (individu) & Outlet (individu) \\
\hline Tipulidae & Diptera & 1 & 1 & 1 \\
Tricortyidae & Ephemeroptera & 0 & 2 & 0 \\
\hline
\end{tabular}

Macrozoobenthic Community Structure

The results of macrozoobenthos sampling at three points, namely the inlet, middle of BBG, and outlet, obtained 16 families of 8 orders of macrozoobenthos. The order that has the highest number of individuals at each point is the Ephemoreptera order with 144 individuals (44 individuals at the inlet, 52 individuals at BBG and 48 individuals at the outlet) and the Trichoptera order totaling 112 individuals (9 individuals at the inlet, 69 individuals at BBG, and 34 individuals at the outlet). The Ephemeroptera orders obtained consist of the Baetidae, Ephemerelidae, and Tricortydae families. The order of Trichoptera that was obtained consisted of the Hydropsychidae and Pryganeidae families. The recapitulation of macrozoobenthic sampling results can be seen in Table 6 .

In this study, the order Ephemeroptera and Trichotera were the ones with the highest abundance, namely $45.9 \%$ and $35.7 \%$ of the total individuals who were successfully obtained. The results of other studies such as March (1988) on the Long Pine Creek River; Sanchez-Fernandes et al [15]. (2006) on the Segura River and Zivic et al. (2001) in the South Morava River also received the order Ephemeroptera and Trichoptera which have high abundance [20]. These types are also often used as indicators of water pollution because they can be found in almost all types of flowing waters and have a fairly good tolerance for organic matter pollution (Castillo et al. al. 2006; Shiels 2010; Wright et al. 2000) $[16,19]$.

Apart from the order Ephemeroptera and Trichoptera, another order that is often used as an indicator of water quality is the order Plecoptera (Voshell et al. 2002) [18]. The EPT index (Ephemeroptera, Plecoptera, Trichoptera) in the Ciliwung river segment of the BBG shows a result of $43 \%$ or there are as many as 7 families so they are classified into the "good" category. According to Bode et al. (1997) found that the value of the range of families was 6-10 families, indicating that the water quality was classified as good quality [2].

Water Quality Status

The results of calculating the water quality status using the Pollution Index (PI) and the Water Quality Index (WQI) show the same water quality status category, namely "lightly polluted" or "good" water quality. However, numerically the PI and WQI index values show a change towards better water quality from the inlet to the middle and the BBG outlet. The results of the PI and WQI calculations can be seen in Table 7.

Table 7. Analysis of the Water Quality Index.

\begin{tabular}{lllll}
\hline \multirow{2}{*}{ Location } & IKA & \multicolumn{3}{c}{ IP } \\
\cline { 2 - 5 } & Value & Ket. & Value & Ket. \\
\hline Inlet & 71,13 & Baik & 2,52 & light pollution \\
BBG & 72,34 & Baik & 2,32 & light pollution \\
Outlet & 77,39 & Baik & 2,08 & light pollution \\
\hline
\end{tabular}

The Ciliwung River in the Bogor City Segment is targeted to have class II water quality. Based on the calculation of the Water Quality Index (WQI), the conditions in the BBG segment from the inlet (WQI 71.13) to the outlet (WQI 77.39) are still classified into the "good" category. Meanwhile, based on the Ciliwung River Pollution Index (PI) in the Bogor Botanical Gardens segment, it is included in the lightly polluted category, both at the inlet (2.25); in the middle of BBG (2.32) and at the outlet (2.08). This water quality status condition is also in accordance with the results of the same physical and chemical quality measurement results (Table 5), which shows that the physical and chemical conditions of the water quality meet Class II quality standards, except for the COD value.

The status of water quality in the Bogor Botanical Gardens Segment is classified as "good" and the level of pollution is classified as "light". These results correspond to both the laboratory analysis results and the WQI index and the PI index. Repair/improvement of the water quality of the Ciliwung River after passing through the Bogor Botanical Gardens is possible due to the reduced input of domestic or industrial pollutants along the Ciliwung River in the Bogor Botanical Gardens segment so that the purification process can take place properly.

Biotic Index

The Biotic Index in this study describes the composition of macrozoobenthos in water. Biotic index is widely used because it is representative enough to reflect the conditions of the aquatic environment. Macrozoobenthic sampling results that have been obtained from three sample points are then analyzed and the biotic index values and contamination categories are obtained (see Table 8).

Table 8. Analysis of the Water Quality Biotic Index.

\begin{tabular}{|c|c|c|c|c|}
\hline \multirow{2}{*}{ Location } & \multicolumn{4}{|c|}{ Indeks Biotik } \\
\hline & $\mathbf{H}^{\prime}$ & Notes & HBI & Notes \\
\hline Inlet & 1,96 & moderately polluted & 4,24 & Very good \\
\hline Center & 1,01 & moderately polluted & 4,09 & Very good \\
\hline Outlet & 1,88 & moderately polluted & 3,90 & Very good \\
\hline
\end{tabular}

Estimation of water quality status using the ShannonWiener diversity index shows a change in water quality after passing BBG. The value of the Diversity Index at the inlet (1.96), BBG center (1.01) and outlet (1.88) is included in the medium polluted category. The results of this HBI index calculation show a decrease in the value of the biotic index, which means a decrease in pollution levels. The average Hilsenhoff biotic index values from the inlet, BBG, and outlet are 4.24, 4.09, and 3.90, respectively. This value falls into the "very good" category, which means that the waters are only slightly polluted with organic matter. The decline in the Hilsenhoff biotic index value indicates that there is an improvement in water quality from the inlet to the $\mathrm{BBG}$ outlet. 
Estimating the status of water quality using the biotic index is very useful to determine the condition of the waters over a long period of time. This is because the parameters used in this index are macrozoobenthos, which almost all of their lives live in a certain water, so they are suitable for accumulating water conditions. The biotic index value in this study shows an improvement in the quality of Ciliwung River water after passing BBG. This is in line with the Water Quality Index (WQI) and the Pollution Index (PI) which show that there are river water purification mechanisms that cause pollutants that enter the river to slowly decompose so that it is getting less and less.

Purification of the Ciliwung River, Bogor Botanical Gardens Segment.

Water quality is the nature of water and the content of living things, substances, energy, or other components in the water. Water quality is expressed in several parameters, namely physical parameters (temperature, turbidity, dissolved solids, etc.), chemical parameters ( $\mathrm{pH}$, dissolved oxygen, BOD, metal content, etc.), and biological parameters (presence of plankton, bacteria, etc.) (Government Regulation No. 82 of 2001 concerning Water Pollution Control).

The purification process that occurs in the Bogor Botanical Gardens segment can run well because there is no input of pollutant waste during the Bogor Botanical Gardens segment. Thus the existence of the Bogor Botanical Gardens provides time for rivers to purify, so that pollutants can be degraded. Ifabiyi (2008) [7] states that the purification ability of a stream is determined by several factors, namely river temperature, river velocity, inorganic materials and also the distribution of vegetation along the river. According to Chooper (1919) purification consists of a process of sedimentation of solid materials and oxidation of dissolved materials. In general, the self-purification process involves the relationship between physical, chemical and biological processes [4].

The physical process that takes place during the purification process is the mechanical decomposition and breakdown of pollutants in the form of solids and dilution of pollutants in the form of liquid. Unesco (1982) states that surface turbulence can increase the decomposition of pollutants. The biological purification process involves the role of organisms in breaking down organic matter. The number of macrozoobenthic species found in this study is in line with water quality estimates. This is because most of the macrozoobenthos are filter feeders and absorb some organic matter and even some pollutants (Oustroumov 2001; Stimson et al. 1996). The chemical process in self-purification that is often studied is the oxidation process. The oxidation process is a process of interaction between oxygen and other substances. Oxidation plays a very important role in the purification process because it converts non-degradable organic and inorganic materials into degradable ones. Oxidation and biological processes are closely related because microorganisms are often catalysts and decomposers in the purification process (Shammaz et al. 2005).

Based on the results of WQI, PI, H ', and HBI analysis, it shows that there is an improvement in water quality in the Ciliwung River, Bogor Botanical Gardens segment. The existence of the Bogor Botanical Gardens which acts as a buffer for the Ciliwung River proves that green open spaces have an important role in the water purification process. Green open spaces on river boundaries can reduce the input of waste directly into the river body. This is in line with research from Hubacikova (2014) which evaluated the relationship between purification and landuse in the Czech Republic and research by Elosegui et al. (1995) in Aguera Stream also found that the purification ability is more effective after passing through green open spaces such as forests or shrubs $[5,6]$.

\section{Conclusion}

1. The results of the analysis of the water quality status of the Ciliwung River in the Bogor Botanical Gardens segment show that the water quality generally meets class II water quality standards, except for COD. Likewise, based on the Water Quality Index, it is categorized as "very good", and based on the Pollution Index, it is categorized as "light" polluted. Based on the diversity index, macrozoobenthos is classified as medium polluted and if using the Hilsenhoff Biotic Index, it is slightly polluted with organic matter.

2. Bogor Botanical Garden is a green open space on the Ciliwung River border which plays an important role in the purification process because there is no domestic pollutant load or other waste that enters the Ciliwung River. This is evidenced by the improvement in the quality of Ciliwung river water in the Bogor Botanical Gardens segment based on the physical-chemical index values (WQI: 71.13 to 77.39, PI: 2.52 to 2.08$)$ and the diversity \& biotic index (H ': 1.20 to 1.64 , HBI: 4.24 to 3.90 ).

\section{Suggestion}

1. It is necessary to monitor river water quality with a biotic index in addition to measurements using physical-chemical parameters. So that it describes the level of water pollution status more completely.

2. It is necessary to repair and arrange the Ciliwung River border outside BBG to increase the purification process more broadly.

\section{References}

[1] Bakti MY. 1991. Karakteristik Komunitas Makro-zoobentos Di Muara Sungai Citarum dalam Hubungannya dengan Pendugaan Pencemaran Perairan di Teluk Jakarta [Skripsi]. Bogor (ID): Institut Pertanian Bogor.

[2] Bode RW, Novak LA, Abele. 1997. Biological Stream Testing. New York (US): Stream Biomonitoring Unit, Bureau of Monitoring and Assesment, Division of Water, NYS Departement of Environmental Conservation, 1997 Cornell University. 
[3] Casttilo LE, Martinez E, Ruepert C, Savage C, Gilek M, Pinnock M, dan Solis E. 2006. Water quality and macroinvertebrate community response following pesticide applications in a banana plantation, Limon Costa Rica. Science of Total Environment. 367: 418-432.

[4] Chooper AD, Cooper EA, dan Heward JA. 1919. On the purifikasi of stream and river. Biochemical Journal. 13 (4): 345-367.

[5] Elosegui A, Arana X, Basaguren A, Pozo J. 1995. Environmetal auditing self purification processes along medium-sized stream. Environmental Management. 19 (6): 931-939.

[6] Hubacikova V, Oppeltova P, Zokustka K, Vetrakova V. 2014. Evaluation of Polluting Source and Self-Cleaning Abillity of Water Flown in Relation to Landuse. Agriculture and Forestry. 6 (4): 67-72.

[7] Ifabiyi IP. 2008. Self Purofocation of a Fresh Water Stream in Ile-lfe: Lesson for Water Management. Jurnal Humaniora and Ecology. 24 (2): 131-137.

[8] Kementrian Lingkungan Hidup. 2003. Keputusan Menteri Negara Lingkungan Hidup Nomor 115 Tahun 2003 Tentang Pedoman Penentuan Status Mutu Air. Jakartan (ID): Menteri Negara Lingkungan Hidup.

[9] Magurran AE. 2004. Measuring Biological Diversity. Malden (US): Blackwell.

[10] Mandaville S. M. 2002. Benthic Macroinvertebrates in Freshwaters- Taxa Tolerance Values, Metrics, and Protocols. Project H-1, Soil \& Water Conservation Society of Metro Halifax [Internet]. [Diunduh pada 2016 Jun 27]. Tersedia pada http://chebucto.ca/Science/SWCS/SWCS.html.

[11] Maret TR. 1988. A water quality assesment using aquatic macroinvertebrates from stream of the Long Pine Creek watershed in Brown country Nebraska. Nebraska Academy of Science. XVI: 69-84.

[12] Ott W R. 1978. Environmental Indiches: Theory and Practice. Michigan (US): Ann Arbor Science.

[13] Odum EP. 1996. Dasar-dasar Ekologi. Yogyakarta (ID): Gadjah Mada University Press.

[14] Pemerintah Republik Indonesia. 2001. Peraturan Pemerintah Nomor 82 Tahun 2001 tentang Pengelolaan Kualitas Air dan Pengendalian Pencemaran Air. Jakarta (ID): Pemerintah Republik Indonesia.

[15] Sanchez-Fernandez D, Abellan P, Mellado A, Millan A. 2006. Are water beetles good indicators of biodiversity in Meditteranian aquatic ecosysten?: the case of the Segura river basin (SE Spain). Biodiversity and Conservation. 15: 45014520 .

[16] Shiels DR. 2010. Implementing landscape indiche to predict stream water quality in an agriculutral settings: an assesment of the lake and river enhacement (LARE) protocal in Mississinewa watershed, East-Central Indiana. Ecological Indicator. 10: 1102-1110.

[17] Trofisa D. 2011. Kajian Beban Pencemar dan Daya Tampung Pencemaran Sungai Ciliwung di Segmen Kota Bogor [Skripsi]. Bogor (ID): Institut Pertanian Bogor.

[18] Voshell Jr, Reese J. 2002. A Guide to Common Freshwater Invertebrates of North America. Blacksburg (VA): The McDonald\& Woodward Publishing Company.

[19] Wright JF, Sutcliffe DW, dan Furse M. 2000. Assesing The Biological Quality Of Fresh Water, RIVPAC And Other Technics. Cumbria (UK): Freshwater Biological Asociation.

[20] Zivic I, Markovic Z, Brajkovic M. 2001. Macrozoobentos in the Pusta Reka river, left tributary of the south Morava river. Biological Science. 53 (3-4): 109-122. 